Jurnal Konstruksi Hukum | ISSN: XXXX | E-ISSN: XXXX Vol. 1, No. 1, September 2020 Hal. 57-62| Available online at https://www.ejournal.warmadewa.ac.id/index.php/jukonhum DOI: https://doi.org/10.22225/jkh.1.1.2129.57-62

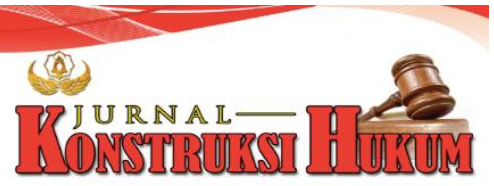

\title{
PENEGAKAN PERDA KOTA DENPASAR DI KAWASAN PROSTITUSI BELANJONG SANUR
}

\author{
Anju Indah Sucita, I Ketut Sukadana, I Made Minggu Widyantara \\ Fakultas Hukum Universitas Warmadewa, Denpasar-Bali, Indonesia
}

\begin{abstract}
Abstrak
Masalah sosial terkait dengan prostitusi terus berkembang dari berbagai kota, begitu juga dengan Kota Denpasar sebagai kota metropolitan terdapat tempat prostitusi disalah satu wilayah Denpasar yaitu di Belanjong Sanur. Dengan Peraturan Daerah (PERDA) Kota Denpasar Nomor 1 tahun 2015 tentang Ketertiban Umum sangat diharapkan penerapannya. Berdasarkan latar belakang masalah tersebut di atas, maka tujuan penelitian ini yaitu untuk mengetahui pelaksanaan Peraturan Daerah (Perda) Kota Denpasar Nomor 1 Tahun 2015 Tentang Ketertiban Umum di wilayah Belanjong Sanur dan untuk menganalisis bagaimana upaya yang dilakukan Pemerintah Kota Denpasar dalam memberantas prostitusi di wilayah Belanjong Sanur. Jenis penelitian ini adalah penilitian hukum empiris dengan menggunakan metode analisis data kualitatif diskriptif. Hasil penelitian menunjukan bahwa pelaksanaan Peraturan Daerah (Perda) Kota Denpasar Nomor 1 Tahun 2015 Tentang Ketertiban Umum di wilayah Belanjong Sanur, yang dilaksanakan oleh Satuan Polisi Pamong Praja (Satpol PP) Kota Denpasar telah terlaksana dengan baik. Selanjutnya, upaya yang dilakukan Pemerintah Kota Denpasar dalam memberantas prostitusi di wilayah Belanjong Sanur, pada garis besarnya, usaha untuk mengatasi prostitusi dapat dibagi menjadi dua, yaitu usaha yang bersifat peventif serta tindakan yang bersifat represif. Secara preventif di wilayah Belanjong Sanur yaitu melakukan sosialisasi dan penyuluhan. Penegakan hukum yang dilakukan Satpol PP adalah dengan melakukan penertiban lokasi prostitusi dan melakukan penangkapan, sebagaimana kewajibannya sebagai penegak Perda No.1 Tahun 2015.
\end{abstract}

Kata Kunci: Peraturan Daerah, Prostitusi, Penegakan Hukum

\begin{abstract}
Social problems related to prostitution continue to develop from various cities, as well as the city of Denpasar as a metropolitan city where there is a place of prostitution in one of the Denpasar areas, namely Belanjong Sanur. With the Regional Regulation (Perda) of Denpasar City Number 1 of 2015 concerning Public Order, it is hoped that its implementation. Based on the background of the problem above, the purpose of this study is to determine the implementation of the Regional Regulation (Perda) of Denpasar City Number 1 of 2015 concerning Public Order in the Belanjong Sanur area and to analyze how the efforts made by the Denpasar City Government in eradicating prostitution in the Belanjong area Sanur. This type of research is empirical legal research using descriptive qualitative data analysis methods. The results showed that the implementation of the Denpasar City Regional Regulation (Perda) Number 1 of 2015 concerning Public Order in the Belanjong Sanur area, which was implemented by the Denpasar City Civil Service Police Unit (Satpol PP) has been carried out well. Furthermore, the efforts made by the Denpasar City Government in eradicating prostitution in the Belanjong Sanur area, in general, the efforts to overcome prostitution can be divided into two, namely efforts that are preventive in nature and actions that are repressive in nature. Preventively in the Belanjong Sanur area, namely conducting socialization and counseling. The law enforcement carried out by Satpol PP is by controlling the location of prostitution and making arrests, as is their obligation as the enforcer of Perda No.1 of 2015 .
\end{abstract}

Keywords: Regional Regulations, Prostitution, Law Enforcement

\section{PENDAHULUAN}

Salah satu bentuk penyimpangan norma atau penyakit masyarakat yang dianggap sebagai masalah sosial adalah prostitusi. Prostitusi memiliki sejarah panjang dan tidak ada habis-habisnya yang terdapat di semua negara di Dunia, tidak terkecuali Indonesia. Perilaku yang dianggap tidak sesuai dengan norma yang telah ditetapkan ini menjadi suatu masalah sosial dalam masyarakat. 
Sekalipun praktik prostitusi ini merupakan perbuatan yang merusak moral dan juga dapat menghancurkan pula keutuhan keluarga namun dalam hukum di Indonesia tidak ada larangan mengenai praktik prostitusi tetapi hanya melarang bagi siapa yang menyediakan tempat atau memudahkan terjadinya praktik prostitusi bila dilihat dari segi yuridis mengenai dasar hukum prostitusi yang dituangkan di dalam Kitab Undang-Undang Hukum Pidana (selanjutnya disebut KUHP) yang merupakan induk hukum pidana. Mengenai kegiatan prostitusi menyangkut diatur dalam ketentuan Pasal 296 KUHP. Namun di sisi lain terdapat Peraturan Daerah (PERDA) Kota Denpasar Nomor 1 tahun 2015 Tentang Ketertiban Umum (selanjutnya disebut PERDA No.1 Tahun 2015. Dalam ketentuan Pasal 39 PERDA No.1 Tahun 2015 mengatur tentang larangan melakukan tindakan prostitusi.

Penegakan hukum terhadap prostitusi masih jauh dari seharusnya. Banyak prostitusi yang tidak tersentuh penegak hukum, disebabkan karena kejahatan ini luput dari pandangan mereka atau banyak tempat-tempat berkedok seperti panti pijat, spa, pub, cafe, dan tempat karaoke hingga salon yang menyiapkan wanita- wanita seksi. Dunia kesehatan juga menunjukkan dan memperingati bahaya penyakit kelamin yang mengerikan seperti HIV/AIDS akibat adanya pelacuran di tengah masyarakat. Masalah-masalah sosial terkait dengan prostitusi terus berkembang, fenomena prostitusi ini menarik untuk dikaji karena dari dulu hingga sekarang tetap berlangsung. Biasanya di kota besar itu pelaku bisnis prostitusi melakukan praktik bisnisnya secara sembunyi-sembunyi, hal tersebut guna menghindari akses yang mungkin timbul dari adanya penolakan dari masyarakat maupun adanya penertiban dan tindakan hukum dari aparat. Tak luput pula Kota Denpasar sebagai kota metropolitan, ditemukan di wilayah Belanjong Sanur, praktik prostitusi yang cukup marak. Salah satu tempat prostitusi yang terkenal adalah di Belanjong Sanur Denpasar Selatan. Pelaku prostitusi di tempat tersebut terdiri dari berbagai usia.

Permasalahan yang dikaji saat ini telah banyak dilakukan sebelumnya seperti Bawole (2013) mengatakan bahwa Pekerja Seks Komersial (PSK) merupakan individu dan warga Negara yang memiliki hak asasi manusia Oleh sebab itu, dengan alasan apapun PSK tidak boleh mendapatkan perlakuan diskriminasi karena perbuatan tersebut melanggar Hak Asasi Manusia. Hak asasi manusia PSK pun perlu dilindungi dan ditegakkan demi terpenuhinya hak asasi dan kebebasan dasar para PSK. Kemudian, Osmanaj (2014) menunjukkan bahwa legalisasi tersebut pelacuran tidak memberikan pengaruh positif apapun terhadap perang melawan perdagangan orang. Pasca legalisasi prostitusi di Belanda jumlah orang yang diperdagangkan meningkat beberapa kali lipat dibandingkan sebelum dilegalkan, apalagi jumlah anak di bawah umur dalam prostitusi meningkat tiga kali lipat dari sebelumnya. Selanjutnya, Pradana (2015); Yanto (2016); Anindia \& Sularto (2019) mengatakan bahwa prostitusi bukan hanya masalah sosial namun juga sebagai tindak pidana. Sejalan dengan pernyataa tersebut, Kristiyanto (2019) mengungkapkan bahwa prostitusi daring tetap menjadi sebuah tindak pidana dapat diproses sesuai aturan aturan hukum. Terakhir, Albright \& D'Adamo (2017) menyatakan bahwa untuk mengurangi perdagangan manusia, petugas kesehatan harus mendukung dekriminalisasi prostitusi sepenuhnya karena dekriminalisasi membantu melemahkan pekerja seks dan membantu melawan marginalisasi politik, sosial, dan budaya pekerja seks.

Berdasarkan latar belakang masalah di atas, maka penelitian baru ini bertujuan untuk mengkaji kebijakan pemerintah dalam pelaksanaan Peraturan Daerah (Perda) Nomor 1 Tahun 2015 Tentang Ketertiban Umum di wilayah Belanjong Sanur dan untuk mengetahui upaya yang dilakukan pemerintah dalam memberantas prostitusi di wilayah Belanjong Sanur.

\section{METODE PENELITIAN}

Penelitian ini didesain dengan menggunakan pendekatan penilitian empiris, yaitu dengan cara membandingkan antara law in the book dengan law in the action, antara teori dengan praktik, sehingga dapat ditemukan kesenjangan hukum dan solusi mengatasinya (Moleong, 2006; Sunggono, 2007). Penelitian ini akan dilakukan di Belanjong Sanur Denpasar Selatan. Pemilihan Belanjong Sanur sebagai lokasi penelitian karena di daerah ini terdapat tempat prostitusi terselubung yang sudah sangat terkenal sejak dulu. Didalam melakukan penelitian hukum empiris, terdapat dua jenis data yang akan digunakan, yaitu:

1. Data primer adalah data yang terdiri dari pengamatan peneliti terhadap realita yang terjadi di lapangan, sehingga berdasarkan hal tersebut peneliti dapat menganalisis fakta-fakta hukum 
yang terjadi (Saptomo, 2009). Adapun bahan-bahan hukum yang dimaksud adalah bahan hukum primer yang mempunyai kekuatan mengikat secara umum (perundang-undangan).

2. Data Sekunder yakni data yang dihimpun oleh peneliti yang berasal dari peraturan perundangundangan, buku-buku, jurnal-jurnal dan bahan hukum cetak lainnya yang relevan dengan isu hukum yang diteliti saat ini (Saptomo, 2009)

Teknik pengumpulan bahan hukum yang digunakan dalam penelitian ini yaitu teknik dokumentasi dan wawancara yang dilakukan dengan wawancara interview. Kemudian, data dianalisis dengan teknik formal yaitu dideskripsikan melalui kata-kata (Sunggono, 2007).

\section{HASIL DAN PEMBAHASAN}

\section{Pelaksanaan Peraturan Daerah (Perda) Kota Denpasar Nomor 1 Tahun 2015 tentang Ketertiban Umum di Wilayah Belanjong Sanur}

Faktor-faktor yang melatarbelakangi seseorang memasuki dunia pelacuran dapat dibagi menjadi dua, yaitu faktor internal dan faktor eksternal (Soejono, 1977). Faktor internal berupa rendahnya standar moral dan nafsu seksual yang dimiliki orang tersebut. Sedangkan faktor eksternal berupa kesulitan ekonomi, korban penipuan, korban kekerasan seksual dan keinginan untuk memperoleh status sosial yang lebih tinggi.

Berdasarkan hasil wawancara dengan I Wayan Wita selaku Kasi Pemerintahan di Kantor Desa Sanur Kauh (Hasil wawancara pada hari Rabu, 11 Maret 2020, Jam 10.25 WITA) menyampaikan beberapa faktor-faktor penyebab terjadinya praktik prostitusi di wilayah Belanjong Sanur yaitu sebagai berikut:

1. Faktor ekonomi, sebagai faktor utama adanya praktik prostitusi yang mana para pemberi jasa tersebut berasal dari kalangan ekonomi lemah dan hampir keseluruhannya adalah orang-orang yang berasal dari luar Provinsi Bali;

2. Faktor lingkungan, sangat mempengaruhi para pemberi jasa dan pengguna jasa prostitusi karena beberapa kali pihak Desa Sanur Kauh sudah berusaha untuk menertibkan wilayah tersebut dari praktik prostitusi namun karena memang lingkungan disekitarnya sangat kuat akan bentuk-bentuk prilaku yang berkaitan dengan penyakit masyarakat termasuk prostitusi sehingga beberapa kali praktik tersebut terus saja muncul;

3. Penegakan hukum, sebagai salah satu faktor yang dianggap sangat lemah, karena pihak Desa Sanur Kauh beberapa kali telah melakukan penertiban bersama dengan Satpol PP Kota Denpasar ke lokasi, namun pada saat para penyedia jasa (germo dan wanita tuna susila) dibawa ke kantor Satpol PP untuk diberikan pengarahan yang selanjutnya diproses melalui sidang pengadilan, namun setelah melalui proses tersebut sanksi yang diberikan hanya berupa denda atau sanksi kurungan yang ringan, sehingga para wanita tuna susila tersebut tidak jera, sehingga para penyedia jasa tersebut kembali lagi ke lokasi dan menjajahkan jasanya kembali.

Selanjutnya, berdasarkan hasil wawancara dengan I Nyoman Suka selaku Anggota di Satuan Polisi Pamong Praja (SATPOL PP) Kota Denpasar (Hasil wawancara pada hari Kamis, 12 Maret 2020, Jam 11.20 WITA) menyampaikan beberapa faktor- faktor penyebab terjadinya praktik prostitusi di wilayah Belanjong Sanur yaitu sebagai berikut :

1. Lokasi, karena berpengaruh pada lokasi yang sepi maka banyak sekali bertumbuh dan berkembang praktik-praktik prostitusi di wilayah tersebut dan tentunya menjadikan sarang penyakit masyarakat;

2. Masyarakat, karena masyarakat pada lokasi prostitusi sudah terbiasa dengan praktik prostitusi tersebut, bahkan ada yang menjadikan hal tersebut sebagai bahan mata pencaharian seperti menjadi penjaga parkir atau penjajah makanan di sekitar lokasi tersebut;

3. Oknum, karena adanya beberapa oknum yang membocorkan informasi sidak-sidak atau penegakan hukum pada para pemberi jasa wanita tuna susila dan germo sehingga pada saat akan disidak lokasi prostitusi telah tertutup dan sepi dari kegiatan;

4. Penegakan hukum, karena proses penegakan hukum dari ketentuan perundang-undangan yang kurang maksimal, dengan penangkapan dari Satpol PP, selanjutnya diserahkan kepada Dinas Sosial Kota Denpasar, yang mana di Dinas Sosial para wanita tuna susila tersebut dilepaskan kembali dan tidak dipulangkan ke asalnya masing-masing;

5. Pendanaan, karena anggaran di Satpol PP Kota Denpasar terbatas, sangat berpengaruh dalam pelaksanaan kegiatan penyidakan dan penegakan Perda terutama dalam proses penangkapan selama di Kantor Satpol PP Kota Denpasar berkaitan dengan konsumsi yang diberikan kepada para wanita tuna susila; 
6. Koordinasi antar instansi, karena masih ditemukannya beberapa instansi yang kurang maksimal dalam koordinasi terutama mengenai proses penangkapan sampai dengan penanganan para wanita tuna susila tersebut.

Kemudian, berdasarkan hasil wawancara dengan I Nyoman Suka selaku Anggota di Satuan Polisi Pamong Praja (SATPOL PP) Kota Denpasar (Hasil wawancara pada hari Kamis, 12 Maret 2020, Jam 11.20 WITA) menyampaikan penegakan hukum berkaitan dengan terjadinya praktik prostitusi di wilayah Belanjong Sanur yaitu:

"Penegakan hukum dilakukan berdasarkan laporan masyarakat, jika itu telah dikonfirmasi mengenai kebenarannya maka dari pihak Satpol PP akan menyiapkan rancangan kegiatan guna persiapan dalam penegakan hukumnya sebagaimana diatur dalam ketentuan Perda Kota Denpasar. Dalam proses penegakan tersebut dilakukan penangkapan pada wanita-wanita tuna susila di lokasi, selanjutnya wanita-wanita tuna susila dibawa ke kantor Satpol PP Kota Denpasar untuk didata identitasnya, bila tidak membawa identitas maka akan dikoordinasikan dengan data dari sistem Dinas Pendudukan dan Catatan Sipil untuk di data ulang. Setelah data lengkap dilanjutkan dengan proses persidangan di Pengadilan Negeri berupa tindak pidana ringan (Tipiring). Lebih banyak putusan pengadilan menentukan sanksi denda pada para wanita tuna susila, jarang yang dijerat dengan kurungan karena masih memperhatikan rasa kemanusian dalam hukum. Setelah ditentukannya sanksinya dan putusannya pada pengadilan, serta telah menyelesaikan masa hukumannya maka para wanita tuna susila dibawa ke Dinas Sosial Kota Denpasar untuk dipulangkan ke daerah asal masing-masing. Namun disinilah ditemukan masalah lagi berkaitan dengan anggaran dana untuk memulangka para wanita tuna susila ke daerah asalnya masing-masing, sehingga terkadang Dinas Sosial melepas kembali para wanita tuna susila. Maka menjadi hal lumrah terkadang seorang wanita tuna susila ditangkap 2 (dua) sampai 3 (tiga) kali di lokasi prostitusi yang sama".

Berdasarkan hasil wawancara dengan I Wayan Wita selaku Kasi Pemerintahan di Kantor Desa Sanur Kauh (Hasil wawancara pada hari Rabu, 11 Maret 2020, Jam 10.25 WITA) menyampaikan penegakan hukum berkaitan dengan terjadinya praktik prostitusi di wilayah Belanjong Sanur yaitu:

1. Pihak desa, telah berupaya melakukan penegakan hukum secara preventif dengan memberikan sosialisasi dan penyuluhan mengenai kesehatan reproduksi dan juga pengawasan terutama berkaitan dengan bentuk- bentuk kejahatan kriminal;

2. Pihak desa tidak bisa melakukan penegakan hukum yang maksimal, karena tidak adanya kewenangan dalam melakukan bentuk penegakan represif, namun desa tetap berupaya melalui sidak-sidak yang rutin dilakukan oleh desa;

3. Pihak desa juga beberapa kali melakukan upaya untuk mengalihkan pekerjaan para germo dan wanita tuna susila tersebut dengan memberikan pemahaman dan pendekatan secara religius dan juga memberikan beberapa pelatihan keahlian lainnya.

\section{Upaya yang Dilakukan Pemerintah Kota Denpasar dalam Memberantas Prostitusi di Wilayah Belanjong Sanur}

Terdapat Peraturan Daerah (PERDA) Kota Denpasar Nomor 1 tahun 2015 tentang Ketertiban Umum (selanjutnya disebut PERDA No.1 Tahun 2015. Dalam ketentuan Pasal 39 PERDA No.1 Tahun 2015 mengatur tentang larangan melakukan tindakan prostitusi.

Berdasarkan hasil wawancara dengan I Nyoman Suka selaku Anggota di Satuan Polisi Pamong

Praja (SATPOL PP) Kota Denpasar (Hasil wawancara pada hari Kamis, 12 Maret 2020, Jam 11.20

WITA) membahas penegakan sanksi bagi para pelaku praktik prostitusi di wilayah Belanjong Sanur yaitu sebagai berikut:

"Penegakan sanksi yang dilakukan oleh Satpol PP Kota Denpasar, berpedoman pada ketentuan dalam Pasal 39 dan Pasal 58 ayat (2) Perda Kota Denpasar Nomor 1 Tahun 2015 Tentang Ketertiban Umum, yang di dalamnya diatur mengenai sanksi kurungan paling lama 6 (enam) bulan dan denda maksimal Rp 50.000.000,- (lima puluh juta rupiah). Lebih banyak kasus-kasus ini sebagai tindak pidana ringan (Tipiring) dan dalam putusannya Hakim memutus sanksi berupa denda. Hal ini disebabkan karena melihat sisi kemanusiannya, bagaimana sebenarnya wanita tuna susila tersebut mencari penghidupan untuk diri kadang keluarganya juga"

Berdasarkan hasil wawancara dengan I Wayan Wita selaku Kasi Pemerintahan di Kantor Desa Sanur Kauh (Hasil wawancara pada hari Rabu, 11 Maret 2020, Jam 10.25 WITA) menyampaikan beberapa 
upaya yang dilakukan guna penanggulangan prostitusi secara preventif di wilayah Belanjong Sanur yaitu sebagai berikut:

I. Pihak desa gencar melakukan sosialisasi dan penyuluhan berkaitan dengan kesehatan reproduksi, semisal penggunaan alat kontrasepsi dan test kesehatan dan pengambilan sampel darah para wanita tuna susila untuk memastikan tidak terjangkit penyakit menular seperti HAIV/AIDS yang bekerjasama dengan pihak ke 3 (tiga);

II. Melakukan sidak-sidak ke lokasi pada malam hari atau jam beroperasinya lokasi prostitusi sekitar pukul 11 malam sampai dengan 2 subuh, untuk memastikan tidak adanya bentukbentuk kejahatan kriminal yang terjadi dilokasi tersebut;

III. Meningkatkan pengawasan terhadap pada germo dan wanita tuna susila, dengan cara pendekatan secara religius agar juga dapat memberikan pemahaman mengenai pekerjaan mereka sehingga kedepannya dapat mencari penghidupan yang lebih baik.

Berdasarkan hasil wawancara dengan I Wayan Wita selaku Kasi Pemerintahan di Kantor Desa Sanur Kauh (Hasil wawancara pada hari Rabu, 11 Maret 2020, Jam 10.25 WITA) menyampaikan beberapa upaya yang dilakukan guna penanggulangan prostitusi secara represif di wilayah Belanjong Sanur yaitu:

"Bahwa pihak desa tidak bisa melakukan penegakan reprsif terhadap praktik prostitusi tersebut karena desa tidak memiliki kewenangan untuk itu, yang berwenang adalah pihak dari Pol.PP Kota Denpasar dan pihak kepolisian. Pernah dulu ada penangkapan dari pihak kepolisian di lokasi prostitusi terhadap germo yang menawarkan wanita tuna susila yang masih dibawah umur sekitar akhir tahun 2019 lalu. Sekarang germo tersebut sudah disidangkan dan masih di pidana penjara sampai saat ini."

Sedangkan Berdasarkan hasil wawancara dengan I Nyoman Suka selaku anggota di Satuan Polisi Pamong Praja (SATPOL PP) Kota Denpasar (Hasil wawancara pada hari Kamis, 12 Maret 2020, Jam 11.20 WITA) menyampaikan beberapa upaya yang dilakukan guna penanggulangan prostitusi secara represif di wilayah Belanjong Sanur yaitu "Penegakan hukum yang dilakukan Satpol PP adalah dengan melakukan penertiban lokasi prostitusi dan melakukan penangkapan, sebagaimana kewajibannya sebagai penegak Perda. Namun yang menjadi masalah adalah setiap dilakukan penangkapan dan penertiban selalu saja masih tumbuh dan muncul tempat-tempat dan wanita tuna susila yang lagi melaukan penawaran jasanya padahal sudah dilarang"

\section{SIMPULAN DAN SARAN}

\section{Simpulan}

Berdasarkan uraian hasil penelitian di atas maka dapat disimpulkan bahwa pelaksanaan Peraturan Daerah (Perda) Kota Denpasar Nomor 1 Tahun 2015 Tentang Ketertiban Umum di wilayah Belanjong Sanur, yang dilaksanakan oleh Satuan Polisi Pamong Praja (Satpol PP) Kota Denpasar kurang efektif karena masih terdapat banyaknya lokasi-lokasi prostitusi yang terdapat di wilayah Belanjong Sanur, hal tersebut dikarenakan lemahnya penegakan hukum yang dilakukan yakni dengan sidak dan penangkapan kepada para wanita tuna susila selanjutnya di data identitas diri mereka, setelah data lengkap dilanjutkan dengan proses persidangan di Pengadilan Negeri berupa tindak pidana ringan (Tipiring). Putusan pengadilan menentukan sanksi denda dan kurungan, namun masih banyaknya wanita tuna susila tersebut yang telah diberikan hukuman masih saja kembali menjalankan profesinya sebagai pekerja seks komersial, seolah-olah hukuman yang diberikan tersebut sama sekali tidak memberikan efek jera kepada para wanita tuna susila tersebut. Kemudian, upaya yang dilakukan Pemerintah Kota Denpasar dalam memberantas prostitusi di wilayah Belanjong Sanur, pada garis besarnya, usaha untuk mengatasi prostitusi dapat dibagi menjadi dua, yaitu usaha yang bersifat peventif serta tindakan yang bersifat represif. Secara preventif di wilayah Belanjong Sanur yaitu melakukan sosialisasi dan penyuluhan berkaitan dengan kesehatan reproduksi, dan meningkatkan pengawasan terhadap pada germo dan wanita tuna susila. Sedangkan upaya yang dilakukan guna penanggulangan prostitusi secara represif di wilayah Belanjong Sanur yaitu dengan penegakan hukum yang dilakukan Satpol PP adalah dengan melakukan penertiban lokasi prostitusi dan melakukan penangkapan, sebagaimana kewajibannya sebagai penegak Perda Kota Denpasar No.1 Tahun 2015.

\section{Saran}


Melalui penelitian ini diharapakan kepada pihak Satuan Polisi Pamong Praja (Satpol PP), agar dapat meningkatkan sidak-sidak yang dilakukan di lokasi-lokasi yang memang menjadi tempat prostitusi, sehingga dapat memberikan efek jera yang maksimal bagi pemberi jasa dan pengguna jasa seksual tersebut dan tentunya sebagai bentuk penegakan terhadap ketertiban masyarakat. Selanjutnya, kepada masyarakat diharapkan agar tetap berkoordinasi dengan instansi-instansi terkait berkaitan dengan pengawasan praktik-praktik prostitusi dan yang paling utama agar para masyarakat yang memang berlokasi di tempat- tempat prostitusi tidak lagi menyediakan tempat bagi mereka yang memberikan jasa seksual tersebut, sehingga dapat menekan perkembangan dari bentuk praktik penyakit masyarakat.

\section{DAFTAR PUSTAKA}

Albright, E., \& D'Adamo, K. (2017). Decreasing human trafficking through sex work decriminalization. AMA Journal of Ethics, 19(1), 122-126.

Anindia, I. A., \& Sularto, R. B. (2019). Kebijakan Hukum Pidana Dalam Upaya Penanggulangan Prostitusi Sebagai Pembaharuan Hukum Pidana. Jurnal Pembangunan Hukum Indonesia, 1(1), $18-30$.

Bawole, M. T. (2013). Kajian Hak Asasi Manusia Terhadap Perlakuan Diskriminasi Kepada Pekerja Seks Komersial. Kajian Hak Asasi, Vol. XXI(3), 12-23.

Kristiyanto, E. N. (2019). Jangkauan Hukum Nasional terhadap Prostitusi Daring (State Laws Coverage on Online Prostitution). Jurnal Penelitian Hukum De Jure, 19(1), 1-10.

Moleong, L. J. (2006). Metodologi Penelitian Kualitatif. Bandung: Rosdakarya.

Osmanaj, E. (2014). The Impact of Legalized Prostitution on Human Trafficking. Academic Journal of Interdisciplinary Studies, 3(2), 103-110.

Pradana, A. M. (2015). Tinjauan Hukum Pidana Terhadap Prostitusi Dan Pertanggungjawaban Pidana Para Pihak Yang Terlibat Dalam Prostitusi. Jurnal Hukum \& Pembangunan, 45(2), 276-307.

Saptomo, A. (2009). Pokok pokok metodologi Penelitian Hukum Empiris Murni. Jakarta: Jakarta Trisakti.

Soejono, D. (1977). Masalah Pelacuran: Ditinjau Dari Segi Hukum dan Kenyataan dalam Masyarakat. Bandung: PT. Karya Nusantara.

Sunggono, B. (2007). Metodelogi Penelitian Hukum (7th ed.). Jakarta: PT. Raja Grafindo Persada.

Yanto, O. (2016). Prostitusi Online Sebagai Kejahatan Kemanusiaan terhadap Anak: Telaah Hukum Islam dan Hukum Positif. AHKAM : Jurnal Ilmu Syariah, 16(2), 187-196. 